\title{
IMPLEMENTATION OF THE LAW AND POLICY IN PROTECTING AND MANAGING THE KRUENG PEUSANGAN WATERSHED, ACEH PROVINCE, INDONESIA
}

\author{
Yanis Rinaldi* \\ Suwarno** \\ Irvianty ${ }^{* * *}$
}

\begin{abstract}
The Krueng Peusangan watershed in the Aceh Province, Indonesia, has an important role in the daily life of residents in the surrounding areas. The watershed serves as a supply of clean water, shelter, food sources, and sources of income for hundreds of thousands of people. Forest encroachment activities, mining, plantations, and land conversion have interrupted the watershed balance. These various activities cause threats of loss of forest area, biodiversity extinction, water crisis, flooding, human-animal conflict, and also global warming and food crisis. Therefore, this article analyses the law and policies issued by the Central, Provincial, and Regency/City Governments related to the management of the Krueng Peusangan Watershed and to examine the legal framework needed for watershed protection and management. This type of research is normative legal research using the regulatory, conceptual, and case approaches. The results revealed that the existing legal framework has not fully protected watershed rescue. The policies issued are still partial and have not been integrated on a regional or sectoral basis. This paper suggests that the Government of Aceh and Regency/City Governments to revise several Qanun, i.e., the Mid-Term Development Plan Qanun, the Watershed Management Qanun, Strategic Environmental Assessment Qanun, Qanun of Environmental Protection and Management Plan, and laws and regulations in the environmental, forestry, plantation and mining sectors.
\end{abstract}

* Faculty of Law, Universitas Syiah Kuala (USK). Email: yanisrinaldi@unsyiah.ac.id.

** Faculty of Mathematics and Natural Sciences, Universitas Syiah Kuala (USK). Email: suwarno@unsyiah.ac.id.

*** Faculty of Mathematics and Natural Sciences, Universitas Syiah Kuala (USK). Email: irvy_bio@unsyiah.ac.id. 
Keywords: policy, watershed, Krueng Peusangan, sustainability.

\title{
PELAKSANAAN UNDANG-UNDANG DAN DASAR DALAM MELINDUNGI DAN MENGURUSKAN KAWASAN TADAHAN KRUENG PEUSANGAN DI PROVINSI ACEH INDONESIA
}

\begin{abstract}
ABSTRAK
Tadahan Krueng Peusangan di Provinsi Aceh, Indonesia, memiliki peranan penting dalam kehidupan sehari-hari penduduk di daerah sekitarnya. Kawasan ini berfungsi sebagai tempat pengumpilan bekalan air bersih, tempat tinggal, sumber makanan, dan sumber pendapatan ratusan ribu orang. Kegiatan pencerobohan hutan, perlombongan, perkebunan, dan penukaran tanah telah mengganggu keseimbangan kawasan ini. Pelbagai aktiviti ini menyebabkan ancaman kehilangan kawasan hutan, kerosakan pelbagai hidupan liar, krisis air, banjir, konflik manusia-haiwan, pemanasan global dan krisis makanan. Oleh karena itu, makalah ini menganalisa undang-undang dan dasar yang dikeluarkan oleh kerajaan pusat, provinsi, dan bandar yang berkaitan dengan pengelolaan kawasan tadahan Krueng Peusangan dan untuk memeriksa kerangka undang-undang yang diperlukan untuk perlindungan dan pengelolaan daerah aliran sungai. Kajian ini berdasarkan kaedah penyelidikan hukum normatif dengan menggunakan pendekatan peraturan, konsepsual, dan kajian kes. Hasil kajian menunjukkan bahawa kerangka undang-undang yang ada belum sepenuhnya melindungi kawasan tadahan dan dasar yang dikeluarkan masih bersifat separa dan belum disatukan secara regional atau sektoral. Makalah ini menunjukkan bahwa Pemerintah Aceh dan Pemerintah Bandar perlu mengkaji semula dasar, iaitu Pelan Pembangunan Pertengahan Undang-undang, Akta Pengurusan Tadahan, Akta Penilaian Lingkungan Strategik, Akta Perlindungan dan Pengurusan Alam Sekitar, dan undang-undang dan peraturan di sektor persekitaran, perhutanan, perladangan dan perlombongan.
\end{abstract}

Kata kunci: dasar alam sekitar, kawasan tadahan Krueng Peusangan, kelestarian kawasan tadahan air. 


\section{BACKGROUND}

The Krueng Peusangan watershed is the main watershed in Aceh Province, covering an area of 238,550 Ha. The watershed crosses five regencies/cities. Its upstream is located in Laut Tawar Lake, Central Aceh District, while its tributaries flow across borders to Bener Meriah, Bireuen, North Aceh, and Lhokseumawe City. The length of the main river from the seafront of Bireuen to Lake Lut Tawar reaches 130,796 kilometers. There are around 107 rivers that flow into Krueng Peusangan, consisting of 12 sub-watersheds. ${ }^{1}$

The Krueng Peusangan watershed has an important role in the daily life of many residents, namely as a source of clean water, shelter, source of food, and income for hundreds of thousands of people. However, some activities in the watershed landscape such as forest encroachment, mining, plantations, and land conversion have disturbed the watershed balance. According to Suhaimi Hamid, Chairperson of the Krueng Peusangan Watershed Forum, currently, the watershed is in a critical position, even in the critical one category nationally. ${ }^{2}$ This is in accordance with the Decree of the Minister of Forestry of the Republic of Indonesia No.SK 328 / MenHut-II / 2009.

The Krueng Peusangan watershed originally contained an area of 297,080 hectares. By the year 2008, it was only left with 235,975 hectares of land. ${ }^{3}$ The contributing factors towards the reduction of the land area are illegal logging and forest fires in the upper watershed areas in the area around Laut Tawar Lake, Central Aceh District. In this region, forest damage is quite alarming, ${ }^{4}$ while commercial use of land

1 Ichwana et.al, "Location Characteristics and Infiltration Patterns: Data, Analysis and Response," Journal of Agricultural Engineering Baseline, 5 No. 2, (2012): 40-47.

2 Junaidi Hanafiah, "Krueng Peusangan, Daerah Aliran Sungai Potensial yang Luput dari Perhatian," Mongabay, accessed 24 January, 2017, http://www.mongabay.co.id/2017/01/24/krueng-peusangan-daerahaliran-sungai-potensial-yang-luput-dari-perhatian/.

3 "Kondisi DAS di Aceh Makin kritis" National kompas, accessed 11 December, 2008, https://nasional.kompas.com/read/2008/12/11/19053531/Kondisi.DAS.d i.Aceh.Makin.Kritis.

4 Khasanah N, et.al, "Rapid Hydrological Review in the Krueng Peusangan watershed, Nanggroe Aceh Darussalam, Sumatra," Icraf Southeast Asia Regional office, World Agroforestry Center (2010): 30. 
in the Laut Tawar Lake area has reached $87.23 \%$, significantly contributing to the change of the hydrology of the catchment area. ${ }^{5}$

The great ecological pressure by human beings on the Krueng Peusangan watershed, if not accompanied by a good legal framework, will contribute to forest loss, biodiversity extinction, water crisis, natural disaster, human-animal conflicts, and further impact on global warming and food crises. The good legal framework referred to the policy, laws, government regulations, presidential regulations, regional regulations, and the decision of the regional head for the protection and management of the Krueng Peusangan watershed.

At present, the Krueng Peusangan watershed is a watershed in the top priority degraded category according to the data from the Ministry of Public Works and the Aceh Provincial Water Resources Office. According to Nugroho, ${ }^{6}$ there are many factors causing the inoperative watershed management system in Indonesia. In addition to the physical and socio-economic problems of the people who are in the watershed, the damage to the watershed is also caused by the legal, and institutional problems that govern the watershed. In this regard, watershed management institutions in the upstream are under the authority of the Ministry of Forestry, while in the central and downstream areas by the Ministry of Public Works and Spatial Planning. The division of authority in the watershed area is causing coordination and overlapping issues, making the protection and sustainable management of the watershed difficult to realize.

The current research objectives are to analyze the legal framework issued by the Central Government, Aceh Provincial Government, and Regency/City Governments related to the Krueng Peusangan watershed and to study the legal framework needed for the protection and management of the Krueng Peusangan watershed.

5 Kutarga, Z.W., Zulkifli, N., Robinson, T, and Sirojuzila, "Study of Spatial Planning of Lake Laut Tawar in the Context of Regional Development in Central Aceh Regency," Wahana Hijau Journal (2008) :31.

6 Nugroho S.P. 2003, New Policy Shifts and Paradigms in Watershed Management in Indonesia, Journal of Environmental Engineering. P3TLBPPT 4, no. 3: 136-142. 


\section{RESEARCH METHODS}

This paper is referred to normative legal research methodology, which used is the statutory, case, and conceptual approach to issue discussed. ${ }^{7}$ This study uses primary data as the main data supported by secondary data which are collected, processed ${ }^{8}$, organized ${ }^{9}$, and grouped in classification according to the subject matter. Data that has been processed, analyzed using a qualitative analysis approach in order to systematically present to the readers. ${ }^{10}$

\section{DISCUSSION}

The term watershed is widely used by several experts with different meanings, some of which equate with area, watershed, or basin drainage. ${ }^{11} \mathrm{~A}$ watershed is a certain land area which is an integral part of a river and its tributaries that functions to store and naturally discharge rainwater to lakes or sea. According to Asdak, ${ }^{12}$ a watershed is an area bounded by mountain ridges where rainwater falling on the area will be accommodated by the ridge of the mountain and will be channelled through small rivers to the main river.

Indonesia has 458 watersheds, and in Aceh, there are 15 (Satuan Wilayah Pengelolaan/River Basin Units/SWP); 2 (two) priority I watersheds (Krueng Aceh and Krueng Peusangan), 3 (three) priority II watersheds, and 10 (ten) priority III watersheds. The Krueng Peusangan watershed is a watershed with the highest priority category

7 Peter Mahmud Marzuki, Legal Research, Revised Edition (Jakarta: Kencana, 2005 p. 134.

8 Wignyosoebroto, Data Processing and Analysis in Community Research Methods (Jakarta: Gramedia, 1997), 270.

9 Moleong L.J, Qualitative Research Methodology (Bandung: Youth Rosdakarya, 2002), 112-113.

10 Latif and Syafei, "Content Analysis (An Alternative Legal Research Method)," Journal of Legal Studies, no. 8 (1994): 49-59; and Soerjono and Abdurrahman, Legal Research Dualism, (Yogjakarta: UMY Faculty of Law, 2007), 130.

11 Sudaryono, "Integrated Watershed Management, Concept of Sustainable Development," Journal of Environmental Technology 3. no. 2 (2002): 153-155.

12 Asdak, Hydrology and Management of Watersheds. (Yogyakarta: Gadjah Mada University Press, 1995), 31-34. 
degraded according to the data from the Ministry of Public Works and the Aceh Provincial Water Resources Office.

At this time, in the Krueng Peusangan watershed landscape, there are excavation $\mathrm{C}$ mining (sand), forest encroachment, illegal logging, and land use change for plantations, so that many oil palm, coffee, cocoa, areca, and other plantations around Krueng Peusangan has been destructed. ${ }^{13}$ Such degraded condition should have a priority to be improved.

\section{Why Pressure Occurred in the Krueng Peusangan Watershed}

\section{a. Population Growth}

Rapid population growth has resulted in high pressure on land. The need for food, water, and shelter resources also increases. Increasing land requirements encourage land use that is not in accordance with its designation. ${ }^{14}$ Watersheds in several places in Indonesia carry a very heavy burden due to their very high population density. ${ }^{15}$ The increase of the human population in an area will undoubtedly have an impact on the environment and natural resources that are around it. Based on data from the Central Statistics Agency in 2018, the total population in the Krueng Peusangan Watershed Landscape was 1,640,007 peoples, showing an increase of around $1.70 \%$ compared to its figure in 2016. The population living in the Krueng Peusangan Watershed Landscape is generally working as farmers, planters, breeders, and fishermen. Overall livelihood is very dependent on nature. The various community extractive activities have harmed the sustainability of the watershed landscape.

13 Junaidi hanafiah, "Krueng Peusangan, Daerah Aliran Sungai Potensial yang Luput dari Perhatian," Mongabay, accessed January 24, 2017, https://www.mongabay.co.id/2017/01/24/krueng-peusangan-daerahaliran-sungai-potensial-yang-luput-dari-perhatian/.

14 Muhammad Fatahilah, "Assessment of Integrated Management of Garang Watershed in Central Java Province," Journal of Geography 10 no. 2 (2013): 136-153.

15 Mahmud, et al, "Assessment of Watershed Status (Case Study of the Serang Sub-watershed)," Agritech Journal 29, no. 4 (2009): 7. 


\section{b. Forestry Sector Business Activities}

In the past 10 years, forestry sector activities have interrupted the balance of the Krueng Peusangan watershed. The total land cover in the Krueng Peusangan Watershed Landscape was 256,464 hectares. Besides, it covers the natural forest area of 79,494 hectares, 2,754 hectares of cultivation area, and the forest area lost from 2006 to 2009 was 1,175 hectares. ${ }^{16}$

The data above shows that there was a great destruction on several districts /cities in the Krueng Peusangan Watershed Landscape in the forestry sector. If this issue is not accompanied by good policies, it will lead to threats of loss of forest, biodiversity extinction, water crisis, disaster threat, human-animal conflict, and consequently lead to a food crisis.

\section{c. Plantation Sector Business Activities}

Aceh Province contains an area of 5,677,081 hectares. The area of land use in the plantation sector covers $21.06 \%$ of the total land area of Aceh, which covers approximately 1,195,528 hectares. The detailed distribution of land use by the licenced company (Hak Guna Usaha/HGU) in the Krueng Peusangan watershed landscape as of March 2015 includes 4,371 hectares in Bireuen and 353 hectares in Central Aceh. For the distribution of community plantations, North Aceh Regency has an area of 70,663 hectares, while Central Aceh covers an area of 64,659 hectares. Additionally, Bener Meriah has an area of 54,047 hectares, and Bireuen has an area of 36,434 hectares. ${ }^{17}$ According to WWF inventory, 34 plantation companies carry out plantation business activities in the Krueng Peusangan Watershed Landscape with a total area of $88,430.87$ hectares. ${ }^{18}$

16 Dede Suhendra, "Peusangan-Jambo Aye-Tamiang Landscape in Aceh Province," in the Focus Group Discussion (Banda Aceh: 2016).

17 "Plantation and Land Conflict in Aceh", Walhi, accessed 2015, http://walhiaceh.com/credit-2015-perkebunan-dan-konflik-lahan-diaceh/."2015 Notes.

18 Dede Suhendra, “Aplikasi Teknologi Lubang Resapan Biopori (Lrb) Di Kelompok Tani Banda Sampie Kecamatan Lembang Jaya Kabupaten Solok," Jurnal Hilirisasi IPTEKS 2, no. 4 (2019): 490-499. 
The data above shows that the pressure of plantation business/activities in the Krueng Peusangan Watershed Landscape has been alarming. If this condition continues, the conversion of forest land for plantation activities will also continue. As a result, forest cover in the Krueng Peusangan watershed will decrease continuously. For this reason, the Aceh Government needs to immediately arrange policies that can inhibit the expansion of plantation businesses in those regions.

\section{d. Mining Sector Business Activities}

WWF inventory suggests that there are 18 mining companies that carry out business activities in the Krueng Peusangan Watershed Landscape covering a total area of 132,001.21 hectares. ${ }^{19}$ Most of the Mining Business Permits are in protected and other allotment areas. ${ }^{20}$ As a result it will have adverse impacts to community and environment. Hence, the Government of Aceh must immediately reorganize policies in the mining sector. If not, it is feared that the sustainability of the landscape will be disrupted, thus affecting climate change, biodiversity, water management and food security.

\section{Analysis of Law and Policies on Watershed Protection and Management in Regional Planning Documents}

a. Aceh Qanun Number 9 of 2012 concerning the Aceh Long-Term Development Plan (RPJPA) 2012-2032.

The Medium-Term Development Plan "RPJP" has included watershed management in the policy direction section on the environment and natural resources, as management of water resources is done by sustainability of maintaining water availability. Utilization of water resources must be carried out optimally to ensure the availability of water through holistic and integrated management between sectors and regions taking into account the principle of hydrology in the framework of watershed management. In addition, every utilization of water resource must pay attention to the Watershed as a planning and management unit.

\footnotetext{
19 Ibid.

$20 \quad I b, 24$
} 
b. Aceh Qanun Number 1 of 2019 concerning the Aceh Medium Term Development Plan (RPJMA) 2017-2022.

The "RPJMA" as the second period of the "RPJP" does not include watershed management programmes. This means that the "RPJMA" does not follow up on the RPJPA policy directives. Whereas in Chapter II about the general picture of conditions in Aceh, several river management problems in the inventory of Aceh have been registered, including: (a) degradation of some watersheds; (b) unintegrated watershed management yet. Recommendations for overcoming these problems are: (1) rehabilitating and reforesting critical watersheds, and (2) implementing integrated river management. Both recommendations are not included in the goals and objectives of the 10 Aceh development missions, improving the quality of integrated infrastructure, and environmentally sustainable.

c. Qanun on Medium-Term Development Plans (RPJM) for Regencies / cities in Central Aceh, Bener Meriah, Bireuen, North Aceh and Lhokseumawe.

District/city governments in the Krueng Peusangan watershed landscape do not include the Krueng Peusangan watershed protection and management policy in their "RPJM", which is considered to be ironic. On the one hand, the five districts/cities have a dependency on the existence of the Krueng Peusangan watershed. On the other hand, there is no concern for protecting and managing the Krueng Peusangan watershed.

\section{Legal Policies for Environment}

\section{a. Law No. 11 of 2006 concerning Aceh Government}

In Article 156 of this law, it is stated that the Government of Aceh and its subsidiaries manage natural resources in Aceh both on land and at sea in the Aceh region which includes mining, (minerals, coal, geothermal), forestry, agriculture, fisheries, and marine under their authority." The attribution authority granted by Article 156 must be seen as capital to better manage Aceh's natural resources, including the Krueng Peusangan watershed. 
In such activities, the Aceh Government and district/city governments, according to Article 149, are obliged to: (1) carry out integrated environmental management by taking into account spatial planning, protecting both living and non-living natural resources and artificial resources, conserving resources the natural environment and its ecosystem, cultural preservation, and biodiversity by taking into account the rights of indigenous peoples and to the maximum extent possible for the welfare of the population; (2) protect, maintain and preserve National Parks and protected areas; and (3) managing protected areas to protect biodiversity and ecology.

The obligations undertaken by the Aceh Government and district/city governments must be seen as a form of responsibility for managing, maintaining, and protecting Aceh's environment and natural resources. Currently, the responsibilities laid down by Law No. 11 of 2006 has not been implemented by the Government of Aceh and District Government.

\section{b. Law No. 32 of 2009 concerning Environmental Protection and Management}

This law requires the Government and Local Governments to prepare a Strategic Environmental Assessment (KLHS) to ensure that the principle of sustainable development has become the basis and is integrated into development. SEA results form the basis for development policies, plans, and/or programmes in an area.

This law also requires that every business and / or activity that impacts on the environment must prepare environmental documents. Activities that have significant impacts must have an Environmental Impact Assessment (EIA), while activities that do not have an important impact must compile an Environmental Management Effort and Environmental Monitoring Efforts (UKL/UPL). Activities/businesses in the Krueng Peusangan Watershed Landscape, such as plantations, mining, and industry, are required to prepare the EIA or "UKL/UPL" to obtain an Environmental Permit. Environmental permits are issued by the Minister, governor, or regent/mayor under their authority. EIA and "UKL/UPL" positions, apart from being a permit requirement, are also the basis for determining environmental feasibility decisions. 
This law also introduces the concept of environmental economic instruments. To preserve the function of the environment, the Government and regional governments must develop and implement environmental economic instruments which consist of development planning and development activities, environmental funding, and incentives and/or disincentives. Environmental funding includes funds for guaranteeing environmental recovery, funds for mitigating pollution and/or damaging or restoring the environment, and trust/aid funds for conservation. One application of the concept of incentives and / or disincentives that are potentially developed in the Krueng Peusangan watershed is the development of a payment system for environmental services. It is considered potential because the Krueng Peusangan watershed passes through several regencies /cities.

\section{c. Law No. 23 of 2014 concerning Regional Government}

This law classifies government affairs into absolute government affairs, concurrent government affairs, and general government affairs. The affairs of absolute government are fully the authority of the Central Government. Concurrent government affairs are government affairs that are divided between the Central Government and the provincial and district/city regions, while the affairs of the general government are the authority of the President as the head of government.

Concurrent government affairs which are the regional authority consist of compulsory governmental affairs and selected governmental affairs. Obligatory government affairs are related to basic needs such as education, social health, public works, spatial planning, public housing and residential areas. Whereas, compulsory government affairs not related to basic services, including land and the environment.

The authority to manage watersheds under this law is included in compulsory matters under the affairs of public works, spatial planning, and the environment. At the central level, the authority for watershed management is under the Directorate General of Watershed and Protection Forest Management, the Ministry of Environment and Forestry. Based on the Minister of Environment Regulation Number P.18 / MENLHK-II / 2015, the Directorate that manages the watershed is the Directorate of Planning and Evaluation of Watershed Control. Meanwhile, in the Aceh Provincial Government, the affairs of 
watershed management are under the Department of Water Resources Management.

\section{d. Law No. 26 of 2007 concerning Spatial Planning}

Spatial planning is a system of spatial planning processes, spatial use, and spatial use control, this planning is done in stages; national spatial planning, provincial spatial planning, and regency/city spatial planning.

The Aceh Spatial Plan (RTRW) is stipulated by Aceh Regional Regulation (Qanun) No. 19 of 2009. Regulations in the "RTRWA" related to the Krueng Peusangan watershed are as follows:

1. Water Resources Network System.

The watershed is the authority of the Aceh Government, covering the Pase-Peusangan watershed.

2. Energy Network Systems

a) Electric power generation.

The development of a power plant uses the Krueng Peusangan Hydroelectric Power Station in Bener Meriah Regency with a potential of 89 MW.

b) Development of electricity transmission and distribution networks.

Construction of new substations at Peusangan I and II substations.

This law gives authority to the Government, Provincial Governments, and Regency / City Governments to control spatial use. The control of spatial use aims to realize spatial order. Efforts to control the use of space from illegal logging in the upper watershed around Lake Laut Tawar have not been able to be overcome. This condition is worsening due to the presence of many $\mathrm{C}$ mining (sand mining) activities and illegal plantations. Such a condition cannot be tolerated and if left unchecked, the damaged watershed condition might deteriorate the environmental and people surrounding. So the role of district/city government to ensure the enforcement of the above law is very essential. 


\section{e. Government Regulation No. 27 of 2012 concerning Environmental Permits}

Environmental Permit is a permit given to everyone who conducts a Business and / or Activity that is required to be an EIA or "UKL-UPL" in the framework of environmental protection and management as a prerequisite for obtaining a Business and / or Activity permit. Environmental permits are issued by the Minister, governors and regents/mayors per their authority. The holder of an Environmental Permit is obliged to (a) comply with the requirements and obligations contained in the Environmental Permit and environmental protection and management permit; (b) prepare and submit an implementation report on the requirements and obligations in the Environmental Permit to the Minister, governor or regent/mayor; and (c) provide guarantee funds for the restoration of environmental functions according to statutory regulations.

This Government Regulation must be used as a guideline for every person in charge of a business and/or activity, including activities/businesses that are present in the Krueng Peusangan watershed landscape. The Government of Aceh and the Government of regency/city must terminate all activities/businesses in the landscape that do not have an environmental permit. Termination of activities/businesses can be done through environmental law enforcement through administrative or criminal channels. Besides, it must also be ensured that the person in charge of a business/activity that has an environmental permit must comply with the obligations of permit documents and legislation in the field of environmental protection and management.

\section{f. Aceh Regional Regulation (Qanun) No. 2 of 2011 concerning Environmental Management}

This Qanun emphasized that environmental management policies, which include the management of watersheds, must pay attention to community rights. This Qanun also gives obligations to the Government of Aceh, district/city government, and the business community to restore the function of local protected areas such as river border areas, water source areas, areas around lakes/reservoirs, and the damaged coastal borders by involving the local community. 
The responsibility of the government to pay attention to community rights has not been carried out as mandated by the Qanun. In some cases, community members become victims as in the instance of the loss of property due to flooding. The Aceh government and district/city governments have also not been able to stop the conversion of forests in the Krueng Peusangan watershed into plantations. Similarly, "Galian C/Sand Excavation" activity without permission, so that erosion often occurs.

\section{Forestry Legal Policy}

\section{a. Law No. 41 of 1999 concerning Forestry jo Law No. 19 of 2004}

This law is a guideline in the implementation of forestry, including forests in the Krueng Peusangan watershed. The implementation of forestry according to this law is aimed at maximizing the prosperity of the people in a lawful and sustainable manner by:

1) guaranteeing the existence of forests with sufficient size and proportional distribution;

2) optimizing various forest functions which include conservation, protection and production functions to achieve balanced, sustainable environmental, social, cultural and economic benefits;

3) increase the carrying capacity of watersheds;

4) increase the ability to develop community capacity and empowerment in a participatory, fair and environmentally friendly manner to create social and economic resilience and resilience to the consequences of external changes; and

5) ensure the equitable and sustainable distribution of benefits. 
Forest management in the Krueng Peusangan watershed landscape is obliged to comply with restrictions contained in the Forestry Law, such as:

1) illegally working and or using and or occupy forest areas;

2) encroaching on forest area;

3) cutting down trees in a forest area with a radius or distance of up to:

a) $\quad 500$ (five hundred) meters from the edge of a reservoir or lake;

b) 200 (two hundred) meters from the edge of the spring and left and right of the river in the swampy area;

c) $\quad 100$ (one hundred) meters from both sides of a river;

d) $\quad 50$ (fifty) meters from both sides of a tributary;

e) 2 (two) times the depth of the abyss from the abyss;

f) $\quad 130$ (one hundred thirty) times the difference between the highest and lowest tides from the shore.

4) burning the forest.

The results of this study showed that many of the legal policies contained in the Forestry Law were violated. The violations occurred in Central Aceh, Bener Meriah, Bireuen, and North Aceh Regencies, in many forms, including, forest encroachment activities, land burning, and forest land conversion.

\section{b. Law No. 5 of 1990 concerning Conservation of Biological Resources and their Ecosystems}

This law becomes a legal umbrella for the implementation of conservation of living natural resources and its ecosystem, including 
those in the Krueng Peusangan Watershed Landscape. Article 4 stated that Conservation of biological natural resources and their ecosystems is the responsibility and obligation of the Government and the community. By making Law No. 5 of 1990 as a legal umbrella, everyone in the Krueng Peusangan Watershed Landscape is prohibited to:

1) take, cut, possess, destroy, maintain, transport and trade protected plants or their parts in a state of life or death;

2) remove protected plants or their parts in a living or dead condition from a place in Indonesia to other places inside or outside Indonesia.

3) injure, kil, store, possess, maintain, transport and trade animals that are protected while alive;

4) save, own, maintain, transport, and trade protected animals that are dead;

5) remove protected animals from one place in Indonesia to other places inside or outside Indonesia;

6) trade-in, store or possess skin, body, or other parts of protected animals or items made from these parts or expel them from a place in Indonesia to other places inside or outside Indonesia; and

7) take, destroy, trade, store, or own eggs and or nests of protected animals.

\section{c. Minister of Forestry Regulation No. P.48 / Menhut-II / 2008 concerning Guidelines for Conflict Management between Humans and Wildlife}

The conflict between humans and wildlife in Aceh tends to increase, including in the Krueng Peusangan Watershed Landscape. According to Suherry from the Bener Meriah Animal Rescue Foundation, 4 residents were recorded killed in the last three years due to being attacked by elephants ${ }^{21}$. Conflicts occur as a result of the damage and

21 Chik Rini, "Mengapa Konflik Manusia dengan Gajah Terus Terjadi di Bener Meriah? Ini Ulasannya," Mongabay, accessed January 27, 2015, 
wildlife habitat being reduced, one of which is caused by the conversion of forest areas into agricultural or plantation areas. In some locations, animal corridors have been turned into cultivation areas such as oil palm plantations. Human and elephant conflicts often occur in Bener Meriah and Bireuen Regencies.

The Minister of Forestry has issued Minister of Forestry Regulation No.P.48 / Menhut-II / 2008 concerning Guidelines for Conflict Management Between Humans and Wildlife. The handling of human-wildlife conflict based on the Minister of Forestry Regulation is carried out with 2 (two) hierarchically related structures. The first structure is in the form of a Coordination Team for Conflict Management between humans and wildlife. This oversees the second structure, which is the Task Force for Conflict Management between humans and wildlife.

The handling of human-wildlife conflict in the Krueng Peusangan watershed landscape has not been effective according to guidelines issued by the Minister of Forestry, as lack of coordination between stakeholders.

\section{d. Qanun Bireuen Regency No. 7 of 2015 concerning Protection of Wildlife}

The purpose of this Qanun is a means of preservation of wild animals to maintain the balance of nature and support the survival and improvement of the quality of life of people in harmony with nature. Whereas the target is to protect wild animals from activities like hunting, capturing, killing, and/or trapping which can cause a decline in wildlife populations in nature and / or cause natural imbalances.

The concept of protection of wildlife carried by this Qanun is carried out in an integrated manner by taking into account the socioeconomic aspects of the community, the balance of the ecosystem, and the juridical aspects. Integrated protection requires that the implementation of programmes aimed at wildlife protection must be mutually integrated, consolidated, and coordinated.

https://www.mongabay.co.id/2015/01/27/mengapa-konflik-manusiadengan-gajah-terus-terjadi-di-bener-meriah-ini-ulasannya/. 
According to Article 6, the Bireuen Regency Government has the authority to carry out wildlife protection, and its implementation is carried out by the Bireuen Regency Wildlife Protection Agency (BPSKB). In carrying out its duties, BPSKB coordinates with BKSDA, relevant agencies, the Aceh Indigenous Council (MAA), Ulama Consultative Council (MPU), Universities, private parties, and other stakeholders.

This Qanun requires the Bireuen Regency Government and the community to (1) reorganize activities on wildlife trails/corridors; (2) build and maintain trajectories/corridors of wildlife that have experienced fragmentation due to development; and (3) maintain wildlife habitats.

The birth of this Qanun must be seen as a form of concern for the Bireuen Regency Government to organize the relationship between humans and wildlife in the Krueng Peusangan watershed.

\section{Legal Policy of Plantation}

\section{a. Law No. 39 of 2014 concerning Plantations}

This law serves as a guideline for managing plantations in Indonesia, including plantations located in the Krueng Peusangan watershed. Article 3 states that the implementation of plantations is aimed at increasing the welfare and prosperity of the people, providing employment and business opportunities, managing and developing Plantation resources optimally, responsibly, sustainably, and also increasing the utilization of estate services.

The implementation of plantation business, in several areas, including in the Krueng Peusangan watershed landscape, has caused various problems. One of the problems include reduced forest cover due to conversion (conversion) of forests for plantation business. In some cases, plantation licenses are given in forest areas or in areas that have environmental functions that must be protected. Also, plantation licenses overlap with other permits; and there are many conflicts between plantation companies and / between communities.

The occurrence of the above problems demonstrates that the plantation legal policies outlined in the Plantation Law have been violated, both by the government in issuing licenses, plantation 
companies, and planters. The Government of Aceh and the Government of Regency / City must regulate illegal plantations in the Krueng Peusangan Watershed Landscape and evaluate the compliance of those responsible for the plantation business in complying with licensing documents and legislative and environmental regulations.

\section{b. Minister of Agriculture Regulation No. 98 / Permentan / OT.140 / 9/2013 concerning Guidelines for Plantation Business Licensing}

This Ministerial Regulation is the legal basis for providing licensing services and implementing plantation business activities. The aim is to provide protection, empowerment of plantation business actors in a fair manner, and provide certainty in the Plantation Business.

As a legal basis for Licensing, this Minister of Agriculture Regulation also applies as a guideline for plantation business licensing in the Krueng Peusangan Watershed. Plantation Business License (IUP) issued by the Governor, must obtain recommendations for conformance with district/city plantation development planning from the regent/mayor. "IUP" issued by the regent/mayor must receive recommendations under the Provincial plantation development planning from the Governor of Aceh.

In granting plantation business permits in the Krueng Peusangan Watershed Landscape, policies must be encouraged to obtain recommendations for conformance with the Aceh Spatial Planning (RTRWA) and Regency Spatial Planning (RTRWK). Against plantation companies holding Cultivation Rights (HGU) in the Krueng Peusangan Watershed, it is necessary to make a policy of reviewing their legalization of permits (IUP, Principle Licenses, location permits) in the form of legal audit procedures and company compliance with permit documents ("IUP", EIA, "UKL/UPL", Corporate Social Responsibility) in the form of a compliance audit.

\section{c. Aceh Qanun No. 6 of 2012 concerning Plantations}

Plantation operations in the Krueng Peusangan watershed landscape must follow this Qanun, which states that each plantation business actor is obliged to (1) maintain environmental functions in a good and 
sustainable manner; (2) prevent environmental damage; and (3) tackle environmental damage.

According to Article 43, plantation business actors must protect the rights of indigenous and tribal peoples. The designation of land for plantation companies does not include customary land held by customary law communities. If the required land is customary, the applicant must first consult with the customary law community and the holder of the customary land rights to obtain an agreement on the land surrender and compensation.

This Qanun was issued by the Government of Aceh to manage plantation businesses in Aceh, including plantations in the Krueng Peusangan watershed landscape.

\section{Legal Policies in Mining}

\section{a. Aceh Qanun No. 15 of 2013 concerning Management of Mineral and Coal Mining}

Article 69 states that the Governor supervises the management of mining businesses carried out by the regency/city government. The supervision referred to includes mining businesses located in the Krueng Peusangan Watershed Landscape. Supervision was conducted by the governor, consisting of supervision of exploration and production operations which include environmental management, reclamation, and post-mining.

With the changes in legislation at the national level, it also had an impact on Qanun No. 15 of 2013. Article 8 Qanun No. 15 of 2013 states that Mining Business Permit is granted by the Governor or Regent / Mayor under their authority. After the issuance of Law No. 23 of 2014, the authority in the field of energy and mineral resources becomes the central and provincial authority, while the authority of regencies/cities is lost. The central authority is only for foreign investment, while the provincial authority is for naming domestic capital.

The Aceh government must immediately revise Qanun No. 15 of 2013 and adjust it to Law No. 23 of 2014 concerning the Regional Government. 


\section{Legal Policy of Water Resources}

\section{a. Government Regulation (PP)No. 37 of 2012 concerning Management of Watersheds}

Consideration of the formation of this PP is due to a decrease in the carrying capacity of watersheds characterized by the occurrence of floods, landslides, erosion, sedimentation, and drought, which can result in disruption of the economy and people's lives. This Government Regulation is intended to coordinate, integrate, synchronize, and synergize watershed management in order to increase the carrying capacity of watersheds.

This Government Regulation governs watershed management from upstream to downstream as a whole. Upstream-downstream watershed management is carried out in accordance with spatial planning and water resources management patterns, based on statutory provisions in the field of spatial planning and water resources. Upstream-downstream watershed management is carried out through the stages of planning, implementation, monitoring, and evaluation, as well as guidance and supervision.

This Government Regulation opens opportunities for community participation in watershed management. Community participation can be done both individually and through watershed management coordination forums. The watershed management coordination forum helps in supporting the integration of watershed management. The watershed management coordination forum has a function to accommodate and channel community aspirations related to watershed management, and contribute ideas in watershed management.

Krueng Peusangan watershed has a Krueng Peusangan Watershed Forum (FDKP), the vision of which is the realization of sustainable forests, water sources, productive land, and prosperous communities in the Peusangan watershed. The FDKP missions are:

1) Building coordination, communication, synchronization and involvement of the parties to encourage and implement Peusangan watershed management in an integrated, directed and sustainable manner. 
2) Developing an integrated, directed and sustainable Peusangan Watershed management strategy.

3) Developing various programmes and activities for forest preservation, water source protection, productive land management, and community welfare in the Peusangan watershed area.

4) Providing input and proposals to policymakers/decisions in the framework of managing the Peusangan Watershed in an integrated, directed and sustainable manner.

The FDKP Work programme are:

1) Exploring the potential of PES (Payments for Environmental Services) Watershed in Aceh;

2) Carrying out focus group discussions discussing the Bener Meriah Hydropower Development Plan;

3) Equipping Mukim's Companion, discussing customary rules;

4) Carrying out focus group discussions discussing Animal Corridor Customary Rules;

5) Developing advocacy strategies for illegal sand mining;

6) Socializing the results of forest cover studies, logging moratorium, spatial study of spatial planning, and mangrove area studies;

7) Socializing mining regulations in Biereun district;

\section{b. Minister of Public Works and Public Housing Regulation No. 01/PRT/M/2016 concerning Procedures for Licensing for Water Resources Management and Use of Water Resources}

Ministerial Regulation becomes a guideline for applicants and licensors in the process of licensing water resource exploitation and licensing the use of water resources. Water Resources Business Permit 
is a permit to obtain and / or exploit Surface Water Resources to conduct business activities. Water Resources Utilization Permit is a permit to obtain and / or exploit Surface Water Resources to carry out non-business activities. The exploitation of water resources and the use of water resources shall be carried out on surface water resources which include rivers, lakes, swamps, and other surface water sources; and seawater on land.

In Article 9, it is emphasized that the exploitation of water resources or the use of water resources can be done by individuals or business entities based on water resources exploitation permits or water resource use permits. Water resources utilization permits or water resource use permits are determined based on water availability and water designation as stated in the water resources management plan in the relevant river area.

\section{c. Aceh Qanun No. 8 of 2004 concerning Protection, Maintenance and Rehabilitation of Water Resources Areas}

This Qanun is a product of the initiative of the Aceh House of Representatives (DPRA). The objectives of this Qanun are to (1) effectively, efficiently and equitably protect, maintain and rehabilitate water source areas; (2) ensure the safety and function of the water source area, to guarantee adequate water supplies for the needs of life and sustainable development.

In Article 4 it is stated that the protection, maintenance, and rehabilitation of the water source area is the responsibility of all parties. District/city governments that benefit from the preservation of the function of the water source area and / or use water for public purposes are obliged to participate in efforts to protect, maintain and rehabilitate the water source area even though the water source area is in another regency/city. The obligations of district/city governments are proportionally determined by the Governor, in accordance with the benefits obtained and the capacity of water utilization in the area.

This Qanun regulates the procedures for protection, maintenance, and rehabilitation of water source areas. In doing so, the following mechanism is necessary. (1) The Governor coordinates the protection, maintenance, and rehabilitation of water source areas which involve inter-regency/city governments; (2) The Regency / City 
Government where the water source is located submits to the Governor before the Aceh Revenue Expenditure Budget Plan (RAPBA) is prepared, concerning protection, maintenance, and rehabilitation activities of the water source area and its copy delivered to the Regent / Mayor whose area benefits from the area the water source; (3) After hearing explanations and opinions from the Regent / Mayor where the water source is located and the Regent/Mayor who benefits from the water source, and taking into account the considerations of the relevant technical agencies, the Governor shall determine the programme to be included in the "RAPBA".

\section{d. Qanun Bireuen Regency No. 8 of 2015 concerning Management and Utilization of Watersheds}

This Qanun carries the concept of Integrated Watershed Management. In Article 4, it is stated that integrated watershed management aims to realize: Coordination, integration, synchronization, and synergy between various parties in the management of natural resources and watershed environment; Optimal water conditions in the watershed, including the amount, quality and distribution; Productive land conditions in accordance with the carrying capacity and capacity of the watershed environment; Improvement of community welfare. The implementation of integrated watershed management is carried out through the following activities: utilization and use of forests, land, and water; Forest restoration and rehabilitation and reclamation of forests and land; and Conservation of forests, land, and water.

To optimize the involvement of various parties in the implementation of Integrated Watershed management policies, the Regent established the Bireuen Watershed Forum, whose membership came from elements of the regional government, the private sector, and the community. The Bireuen Watershed Forum has the following tasks:

1) formulate operational policies and strategies for Bireuen Regency Integrated Watershed Management;

2) carry out coordination and consultation to align interests between sectors, between regions and between stakeholders in the Integrated Watershed Management at the Bireuen District Level; 
3) draw up an Integrated Watershed Management Plan for rivers across the Bireuen Regency;

4) develop control mechanisms for the of forests and land along the watershed carried out by sectoral agencies, business entities, and communities;

5) manage Integrated Watershed Management funds sourced from the business world and the community in a transparent and accountable manner.

The presence of this Qanun is very beneficial for the protection and management of the Krueng Peusangan watershed. However, because ecosystem-based watershed management is not an administrative area, the participation of other regencies/cities that are in the Krueng Peusangan watershed landscape is very much needed.

\section{CONCLUSIONS AND RECOMMENDATIONS}

The availability of law and policies for the protection and management of the Krueng Peusangan Watershed, both issued by the Central Government, Provincial Governments, and Regency / City Governments is not sufficient to realize sustainability of watersheds. Some rules need to be revised, renew, and made enforced. Based on the conclusions, the recommendations of this study are as follows:

The Government of Aceh and the Regency / City should immediately revise the Mid-Term Development Plan Qanun by including the management of the Krueng Peusangan Watershed as mandated by the Aceh Long-Term Development Plan. Also, they should immediately compile the Aceh Qanun on Watershed Management, the Strategic Environmental Assessment Qanun (KLHS), and the Qanun Krueng Peusangan Watershed Protection and Environmental Management Plan (RPPLH). Indeed, the legal enforcement issue should be taken into account. 